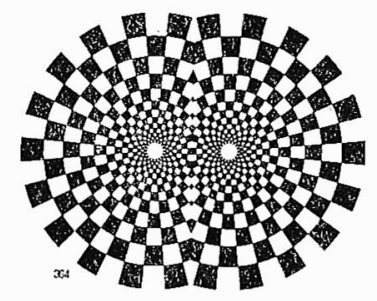

\title{
無機化合物粉体のカプセ ル化を伴う重合反応
}

\author{
小野堯之・山口＼cjkstart格
}

Takayuki Ono· Tadashi Yamaguchi, 宮城工業高等專門学校

\section{1.はじめに}

近年の科学技術の進歩発展に伴い, 材料として要求 される物性がますます多様化, 高性能化してきたこと から各種素材を組み合わせた複合材料がさまざまな分 野で注目されている，無機化合物粉体をポリマーに分 散させた材料もそらいら複合材料の一つで, ゴム，フ ュ.ノール樹脂, 塗料などの工業では比較的早くから行 なわれてきたものでする。このよらな不均一，多成分 系材料では異種界面の相互作用, 分散性などが材料の 性能を決定する大きな要因となる、このため，これら の分散系複合材料を製造する場合には無機化合物粉体 の表面処理やポリマーの改質をしたのらに混練, 成形 丸行ない, 分散性の向上, 結合力の強化を図るのが普 通である。

無機粉体の表面処理法としてはこれまで多くの試 みゆがなされて和り，なかでもシラン和よびチタネー ト系カップリング剂による処理法が広く行なわれてい る.しかし,複合材料の製造に拈けるこのような改質処 理法は，学術的にもまだ不明な点が多く、実際面でもか なり高度な技術を必要とし，その後の混練のための設 備費, 運転エネルギーも大きい。こらいった問題点を 高分子合成反応を用いて解決しようとする研究もいく つか知られており、Hamann らの総説がある.たと充 ばシリカ,クレー，カーボンブラックなぞに重合開始 剤, ビニルモノマーなどを吸着あるいは化学結合させ

\footnotetext{
Encapsulation of Inorganic Powder in the Polymeri-
} zation Reaction

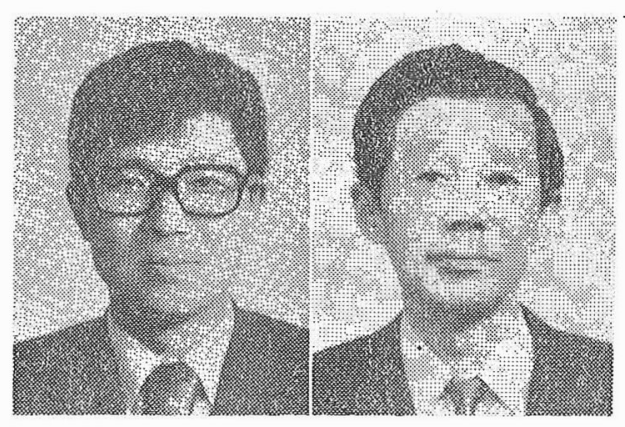

て重合するか，無機固体表面のメカノケミカル反応に よる重合例などがあり，わが国では大北3，松本 ${ }^{4} ら$. の研究がある.これらの例では, ポリマーの一部は溶媒: によっても無機粉体から抽出されない，いわゆるグラ フトポリマーの得られる場合が多いが，適用できる無 機化合物がかなり限定されること，工程が複雑かつ繁: 雑なこと，放射線を使用することなど工業的製造法と してはやはりいくつかの難点を有している.

著者らは,ポリマー, 無機化合物間に相互作用をるつ。 複合体を通常の重合反応で容易に合成でき，しかもす べての無機化合物に適用可能な方法を種々検討してき た. その結果, 無機化合物粉体の存在下, 水媒体中で ビニルモノマーの重合を行ならことによりほとんどの： 水難溶性熙機粉体がポりマーで均一から強固にカプセ ル化されること, これは直接, 樹脂成形加工が可能で 分散性に優れた複合材料が得られることを見い出し た. この複合体は表面処理, 混練工程が全く理想的に. 行なわれたとも考兄られるものであり，従来の製造工： 程の改善のみならず, 材料物性の向上, さららには無機: 素材とポリマーの長所を兼ね備光た新しい材料として も期待される. 以下その合成法, 複合体の性質, 応用 などについて概説する.

\section{2. 複合体の合成法}

無機化合物 ポリマー複合体の合成はかき混ぜ装置: を備えた丸底フラスコに無機化合物粉体, 水, ビニル モノマーを加え, $40 \sim 65^{\circ} \mathrm{C}$ に保ったのち開始剤（主. として亜硫酸水素イオンを生成する物質）を添加し，

小野鉦之 宫城工業高等專門学校 (981-12 名取市愛鳥塩手字野田山 48) 教授. 工博 (写真左)

昭和 38 年秋田大学鉣山学部卒. $38 \sim 51$ 年東北大工学部助手, $52 \sim 55$ 年助教授を経て 55 年 4 月より現職. 専門方高分子化学, 材料化学.

く趣味〉スポーツ，読書

山口 格 同上, 校長·工博 (写真右)

昭和 24 年東北大学工学部卒. $24 \sim 33$ 年東北大助手, 33 年助教授, 38 * 年教授となり 58 年退官. 東北大学名誉教授. 58 年 4 月より現職. 専. 門结高分子化学.

<趣味〉旅行，読畫 


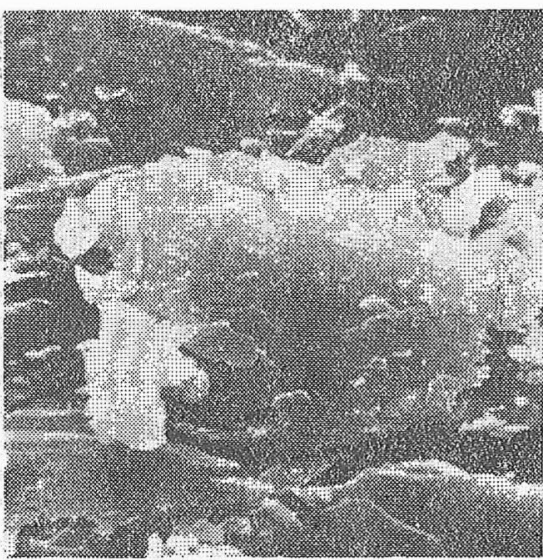

(a)

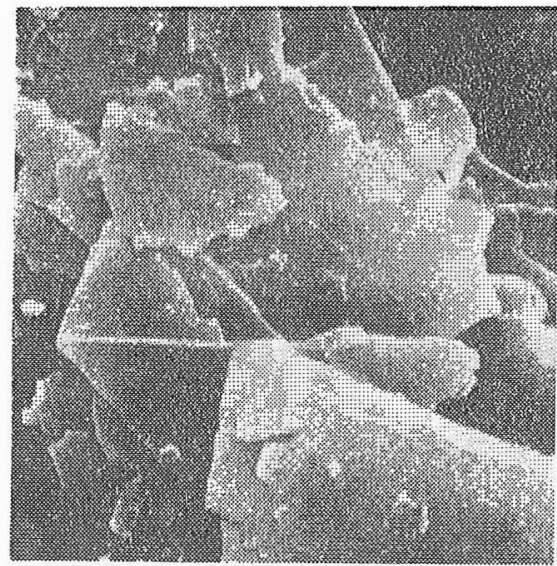

(a)

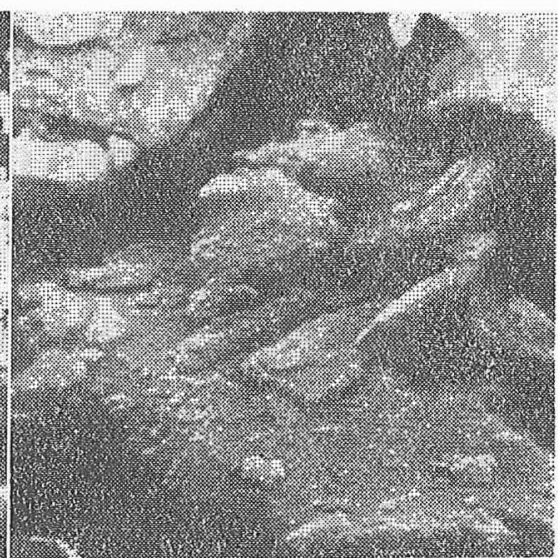

(b)

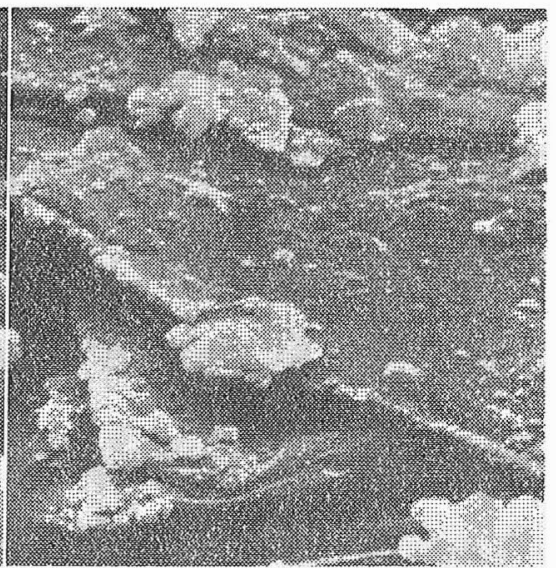

(b)
写真 1 アルミノシりゲ ート (a) と PM MAでカプセル化 されたアルミノシ リケート（b）の SEM 写真

$(\times 5,000)$
30 分〜 3 時間程度かき混ぜながら重合させる，反応 終了時, 粉体はフラスュ底部に沈降し, 水溶液は汪と んどの場合透明でュロイド状ポリマーは存在しない. 沪別した粉体の形状は無機化合物粉体とほぼ同様であ り，走查電子顕微鏡 (SEM) などによって無機粉体表 面がポリマーで良好にカプセル化されていることが認 められた，写真 $1 ， 2$ に無機粉体和よび複合体の SEM 写真例を示した. このよらなカプセル化法は各種の金

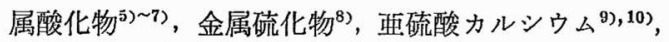
セッコウ 11) 13), 黑鉛(4),15), フィロケイ酸塩鉱物 ${ }^{16)}$, 金属粉体 ${ }^{17), 18)}$ などの 水難溶性無機粉体扣よびメタク リル酸メチルを主とするほとんどのビニルモノマーに 適用可能であった.

\section{3. 重合機構およびカプセル化機構}

重合開始剂として亜硫酸などを使用した場合の重合 速度は遷移金属を含む化合物の存在下で著しく大き (5) 7). また得られるポリマーは 1 分子当たり $1 \sim 2$ 個のスルホナート基あるいは硫酸エステル基を有して

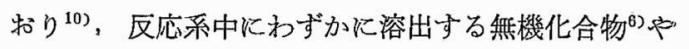
微量生成してくる界面活性作用をるつ水溶性の新有機 化合物 ${ }^{10)}$ の構造決定などから無機粉体が遷䔟金属を含 む場合は亜硫酸水素イオンとの僄移金属イオンとレド ックス反応で生ずる亜硫酸水素ラジカルで, また遷移 金属を含まない場合は反応系中に存在する酸素と亜硫 酸水素イオンからできるラジカルによって重合が開始 され ${ }^{19)}$, 初期には主として水相で重合が進行するもの と考觉られる.

カプセル化機構について性静置重合 ${ }^{8)}$ な゙の結果か ら，ポリマー末端基と無機粉体の表面電荷とが互いに 影響を及添していることが推定されたたで, コロイド 滴定法 ${ }^{20)}$ で無機汾体括よび別個に合成したコロイド状 ポリマーの表面電荷を測定し，また電気泳動法により ら-電位を求めた。これらの結果から业硫酸開始系では 多くの無機粉体は反応系の $\mathrm{pH}$ が低下することなどに よって正の電荷を, 得られるポリマーはとの陰イオン 末端基に基づく負電荷をもつことが明らかになった。 表 1 に数種の無機粉体の表面電荷の值と重合反応で生 


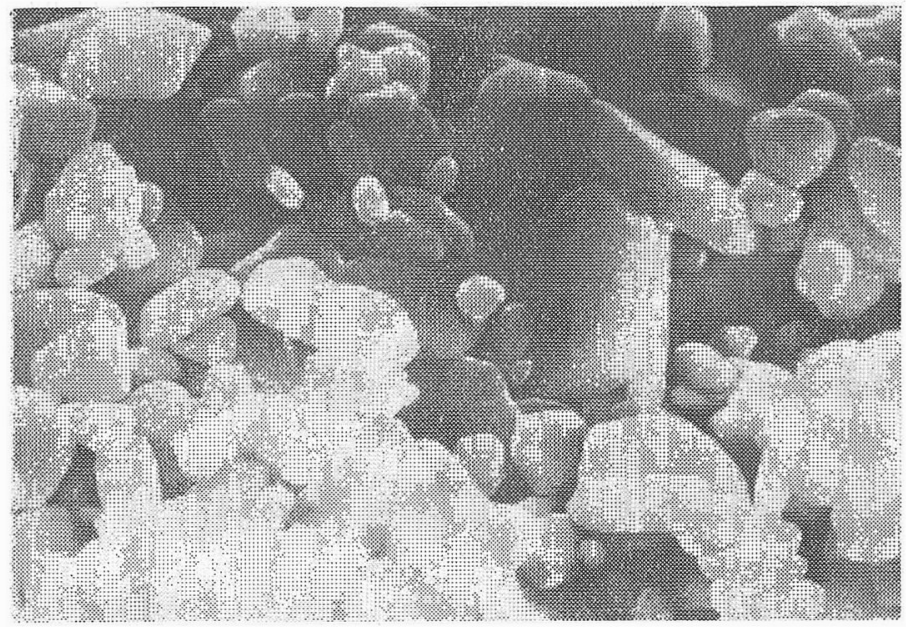

成するカプセル化ポリマーの比率を示したが，表面電 荷の大きな粉体潘ど負電荷をるつポリマーで良好にカ プセル化されている，表 2 は等電点の異なる金属酸化 物存在下の重合を亜硫酸以外の重合開始剂で行なった 結果を示したものである.中性付近で正の ろ-電位を もつアルミナの場合怔のポリマー末端を与光る開始 剂 $2,2^{\prime}$-アゾビス(2-アミジノプロパソ)塩酸塩(AIBA. $2 \mathrm{HCl}$ )よりも負のポリマー末端を与学る過硫酸カリウ ム (KPS) でカプセル化が良好になされるのに対し， 負のら一電位を有するシリカでは AIBA・ $2 \mathrm{HCl}$ 開始系 でカプセル化が容易進行する。このようなことは電 位決定イオンを用いて正あるいは負に带電させた硫酸

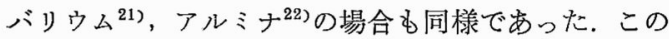
ような結果からポリマーによる無機化合物粉体のカプ セル化機構としては先に述べた反応系にわずかに溶出 してくる金属イオン，界面活性作用を有する新化合物 などの影響も無視はできないものの，主としで無機粉

表 1 無機粉体の表面電荷とカプセル化

\begin{tabular}{lcc}
\hline 無機粉体 & $\begin{array}{c}\text { 表面電荷 } \\
\times 10^{5} \text { Faraday } / g\end{array}$ & $\begin{array}{c}\text { 生成全ポリマー } \\
\text { 中のカ゚セル化 } \\
\text { ポリー/wt } \%\end{array}$ \\
\hline $\mathrm{FeS}$ & 6.30 & 100 \\
Vein graphite & 3.32 & 100 \\
$\mathrm{CuS}$ & 2.53 & 100 \\
$\mathrm{Fe} \mathrm{O}_{3}$ & 2.48 & 100 \\
$\mathrm{CdS}$ & 1.82 & 85 \\
$\mathrm{Cu}$ & 0.98 & 28 \\
$\mathrm{HgS}$ & 0.55 & 13 \\
$\mathrm{SiO}_{2}$ & 0.45 & 12 \\
\hline
\end{tabular}

モノマー: MMA, 開始骺: $\mathrm{H}_{2} \mathrm{SO}_{3}, 40 \sim 50^{\circ} \mathrm{C}, 0.5$ $\sim 5 \mathrm{~h}$
体表面の電荷と成長中のポリマーあるいは生成したポ リマー末端基とよる電荷との静電的相互作用が重合の 初期段階で大きな影響を及ぼして特り，炎の後, 無機 粉体表面上のポリマー層にビニルモノマーが溶解して さらに重合が進行し，良好なカプセル化がなされるむ のと考觉られる.

\section{4. 複合体の性質とその応用}

本重合系で得られるカプセル化複合体を良溶媒で十 分ソックスレー抽出しても少量のポリマーは抽出され ないで無機粉体表面に残る場合が多く, また熱分析で は単ヒブレンドした複合体よりもポりマーの吸熱ピー ク温度がかなり高い10)。さらに複合体の融液粘度 ${ }^{23)}$, 動的粘弾性 ${ }^{24}$ などの測定結果からカプセル化ポリマー は無機粉体表面と強い相互作用を有していると考它ら 礼る.またこの複合体は他の方法で得た複合体と比較 してコロナ帯電特性が格段《優れて括り ${ }^{25)}$, この測定

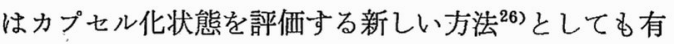
用である。

以上の上らなことから本複合体洨分散性の良い顔

表 2 金属酸化物粉体のカプセル化

\begin{tabular}{|c|c|c|c|}
\hline 金属酸化物 & $\begin{array}{c}\zeta \text {-霓位 } \\
\mathrm{mV}\end{array}$ & 重合開始㨈 & $\begin{array}{l}\text { 生成全ポリマー } \\
\text { 中のカプセル化 } \\
\text { ポリマー/wt\% }\end{array}$ \\
\hline \multirow{2}{*}{$\mathrm{Al}_{2} \mathrm{O}_{3}$} & \multirow{2}{*}{+27} & $\mathrm{AIBA} \cdot 2 \mathrm{HCl}$ & 32 \\
\hline & & KPS & 100 \\
\hline \multirow{2}{*}{$\mathrm{TiO}_{2}$} & \multirow{2}{*}{-10} & $\mathrm{AIBA} \cdot 2 \mathrm{HCl}$ & 73 \\
\hline & & KPS & 66 \\
\hline \multirow{2}{*}{$\mathrm{SiO}_{2}$} & \multirow{2}{*}{-26} & $\mathrm{AIBA} \cdot 2 \mathrm{HCl}$ & 95 \\
\hline & & KPS & 3. \\
\hline
\end{tabular}

モ/マー: MMA, $60 \sim 65^{\circ} \mathrm{C}, 0.5 \mathrm{~h}$

高分子 34 巻 2 月号（1985年） 
料, フィラー, 静電粉体塗料として興味深い。またポ リマー含有量が少なくても樹脂成形が容易で機械的強 度も大きいことから，優れた導電性プラスチック ${ }^{27)}$ 打 よび電磁シールド材が, 磁性粉体からは磁気特性, 加 工性に優れたプラステック磁石 ${ }^{28)}$, 磁性爆薬 ${ }^{29)}$, 磁性 トナーなどが得られ，成形が困難で安定性にそしいセ ラミックス粉体などへの応用もなされている。また音 響材料, 電子デバイス用放熱絶縁板 ${ }^{27)}$ や局所治療用磁 性カプセル，X線造影剂，人工骨，人工歯，人工腎な ぞの医療材料への応用，さらに压電 焦電材などの変 換機能，センサ機能，分離機能を有する材料への応用 が考えられる．また本法は古文化財の保存・修復法 ${ }^{30}$ としても有用であることがすでに見い出されている.

\section{5.おわりに}

ビニルモノマーの重合反応を利用したポリマーによ る無機化合物粉体のカプセル化について概説したが， 本系の反応機構のすべてが明らかにされているわけで はない。しかし無機粉体とポリマーの表面電荷を考慮 して重合条件を適宜選択すれば，注とんどすべての粉 体をポリマーでほぼ均一にカプセル化することができ る. 本法は従来から知られているマイクロカプセル化 法のいずれと比較してもかなり優れた特徽をもって物 り，特にミクロン以下の微粒子をるポリマーで 1 個 1 個カプセル化することが可能である.

最近, 長井 ${ }^{31}$ は界面活性剂型モノマーをシリカ粉体 に吸着させたのら重合を行ない，また古沢ら ${ }^{32}$ はシリ カ粒子にセルロース誘導体を吸着させてスチレンの重 合を行ならことにより粉体表面がポリマーでカプセル 化されることを郝告して扣り，板橋ら ${ }^{33)}$ 無機粉体を カプセル化したのら種々の官能基を導入して有機物と 重金属イオンを同時に除去できる複合吸着剤を得てい る.このよらな種々の重合反応を用いて得られるカプ セル化複合体はこれまでの成形体，構造材の材料物性 の向上などにとどまらず，無機掞よび有機素材の特徴 を十分発現でさる新しい機能材料として，今後広範な 用途が期待できるるのと思われる.

\section{文献}

1）高橋 浩, 荻原茂示: 粉休一理論と応用, 丸善 (1979) p. 204

2) R. Kroker, M. Schneider, K. Hamann: Progr. Org. Coatings, 1, 23 (1972)

3) 大北能一：カーボンブラックのグラフト化, ラバ 一ダイジニスト社 (1983)

4) 大久保政芳, 渡谷誠治, 黒田敏一. 松本恒隆 : 日 本接着協会誌, 20, 104 (1984)

5) T. Yamaguchi, H. Tanaka, A. B. Moustafa,
T. Ono: Chem. \& Ind., 619 (1974)

6) 山口格, 田中弘文, 小野㚃之, 遠藤道雄, 伊藤 博，板橋 修：高分子諭文集，32，120 (1975)

7) 山口格, 田中弘文, 小野堯之, 板橋修, 伊藤 搏：高分子論文集，32，126(1975)

8）山口格，小野堯之, 大原周一：高分子諭文集, 34, 413 (1977)

9) T. Yamaguchi, T. Ono, H. Ito: Angew. Makro. Chem., 32, 177 (1973)

10) 山口格, 小野兟之, 伊藤 博：日本化学会誌, 1760 (1980)

11）川口格，田中弘文，小野䤞之，板橋修，棉原 善朗, 高井雅一: 石高亡石灰, 141，62，(1976)

12) 山口格. 田中弘文, 小野軠之, 板橋修. 半田 喜代二：石育と石灰，141，68（1976）

13）山口格, 小野堯之, 板橋修, 佐々木千明: 石 膏之石灰, 141，74（1976）

14) T. Yamaguchi, T. Ono, Y. Saito: Chem. \& Ind., 783 (1974)

15) T. Yamaguchi, T. Ono, Y. Saito, S. Ohara: Angew. Makro. Chem., 53, 65 (1976)

16）小野䓨之, 高撟 勉, 今野雅志, 三河寿則：宮城 高専研呪紀要, 18, 57 (1982)

17) T. Yamaguchi, T. Ono, H. Hasegawa: Chem. \& Ind., 748 (1975)

18) T. Yamaguchi, T. Ono, M. Sekine: Advances in Organic Coatings Science \& Technology, 3, 123 (1980)

19）山口格, 小野堯之, 大原周一：高分子論文集, 37, 483 (1980)

20) 千手諒一：コロイド滴定法, 南江堂 (1969)

21）山口格, 小野瑴之, 野沢正行, 関根正裕: 高分 子論文集，38，435(1981)

22）山口格，小野劫之，野沢正行，関根正裕，岩井 隆賀，岡田知之：高分子諭文集，40，259 (1983)

23) K. Iwakura, T. Fujimura: J. Appl. Polym. Sci., 24, 975 (1979)

24) 山口格, 野沢正行, 関根正裕, 岩井隆賀: Polymer Preprints, Japan, 32, 620 (1983)

25) 金子富上男, 竹内 学, 長坂秀雄 : 材料, 27, 638 (1978)

26）山口格, 野沢正行, 関根正裕, 岡田知之: Polymer Preprints, Japan, 32, 621 (1983)

27) 小野偓之: Polymer Preprints, Japan, 33, 2755 (1984)

28) T. Yamaguchi, T. Ono, S. Ogasawara: Chem. \& Ind., 847 (1978)

29) 可田道利, 新妻茂雄, 横山俊彦: 東北金属技報, 9, 33 (1982)

30) 小忬堯之：保存科学, 18, 57 (1979)

31) 長井勝利：高分子, 33，686 (1984)

32) 古潀邦夫，木村吉宏，田川徹：高分子論文集， 40, 697 (1983)

33) 板橋 修, 佐藤 誠, 生島 豊, 後藤富雄: 化学 系学協会連合東北地方大会講演予稿集, p. 17 (1984); 日本化学会第 49 春季年会講演予稿 集, p. 236 (1984) 